\title{
EDITOR'S NOTE:
}

\section{Brazil, the weakest link of BRICS?}

Many readers and contributors of AUSTRAL, from the most diverse countries, have been asking us: "what is happening in Brazil?" In fact, there is no economic crisis or conjunctural problems that could serve as an explanation for the recent demonstrations. After about a decade of intense international projection, economic growth and successful social policies, Brazil under Dilma's presidency was hit in June 2013 by a wave of strange protests, characterized by contradictory motivations. The achievement accomplished by President Lula of making Brazil the host-country of the 2014 FIFA World Cup and Rio de Janeiro the host-city of 2016 Olympic Games seem subtly in risk. Brazil, as most countries, endures the chaos of megacities and urgently needs infrastructure updates, which would be propitiated by the World Cup and the Olympics.

It is correct that the government has been trying to stimulate the expenditure of $\mathrm{C}$ and $\mathrm{D}$ classes without jeopardizing $\mathrm{A}$ and $\mathrm{B}$ classes, and, in order to do that, it facilitates the acquisition of cars rather than the development and use of public transportation, which increases urban chaos. And, concerning this last aspect, it does not perform differently from the Military Regime or the Neoliberal Era of Fernando Collor de Mello and Fernando Henrique Cardoso. At the same time, it creates a culture of consumerism, with broadened rights and no correspondent duties or constructive and collective ideological motivations, just a cult of individualism.

The old Brazilian elite resents from the increasing concurrence of ascendant classes for an outdated infrastructure and a deficient service sector, which are increasingly insufficient. A population depoliticized by the physiologic alliances of a coalition government and the indifferentiation of party programs aggravate the situation. However, the scattered dissatisfaction per se is not able to produce such street rallies. 
For more than two decades, national defense, internal security and intelligence sectors have been neglected, even by the present government, influenced by a post-modern perspective and (mis)guided by an agenda emanating from certain circles of great powers. In this sense, Dilma Rousseff administration demonstrates some discontinuity in relation to President Lula's, since it has a very technical profile on the one hand, and it is politically vacillating, on the other. Even its diplomacy evinces signs of regression, in a government dangerously vulnerable to and permeated by the political action of NGOs and public and private foreign foundations. Public policies are launched, fomenting social movements of ambiguous guidance, which turn themselves against the government that avails them itself. In a broad world crisis, protesters demand privileges that are disappearing even in the ancient and prosperous states of the North, without being disposed to make any efforts.

The social networks, technologically manageable and politically influenced by foreign actors, easily capture the disoriented and inexperienced demonstrators, characterized by a naive idealism. The old Brazilian conservatives and both internal and external agents provocateurs take action, as well as economic pressure groups in search for specific and obscure advantages and ultra-leftists organizations. The government then demonstrates unreadiness, reacting in a faltering and erratic way, further fueling the protests. Not by chance, the building of the Ministry of Foreign Affairs in Brasília (Itamaraty) and public institutions were the main targets of vandalism.

As for the other BRICS, China keeps its path of development, sovereignty and stability, while Russia even displays a refurbished international political will, as in the Syrian case. India, on its turn, is naturally social and culturally unstable, and South Africa turns out blocked by the contradictory political pact that provided the end of juridical Apartheid. It has lost its leading role even in Africa, where Angola emerges as an important player. Respect to Brazil, the country seems to be losing its disposal to respond to challenges like the U.S. electronic espionage and the international incident of the Bolivian presidential carrier in Europe. A state that granted political asylum to Paraguayan right-wing dictators, to the Italian far-left militant Battisti (perpetrator of many murders) and to the confused episode involving the removal of the Bolivian senator Roger Pinto from the Brazilian embassy in La Paz, Brazil now demonstrates fear of doing so to Edward Snowden. The Roger 
Pinto affair implied the dismissal of Chancellor Patriota and the admission of Ambassador Luiz Alberto Figueiredo. Major changes are not previewed, but Itamaraty must become more active and be more closely monitored by President Dilma.

In the same direction, Brazil vacillates regarding international selective criteria that weaken economic development in the energetic and infrastructural areas. A BRICS member geographically distant from the Eurasian core, Brazil struggles with identity problems. A nation historically and culturally recognized by the predominance of miscegenation, it surrenders to the pseudomulticulturalism that ultimately defines it as "Western", with minorities fragmenting the nation-building. Without that, there is no national project and consequently there cannot be an advance in economic-social sustained development. But what is at stake in the external arena is the realignment of Brazilian diplomacy and the estrangement from the other BRICS.

In the domestic arena, the focus is the 2014 elections, following the opposition defeat in important cities, like São Paulo. Therefore, amidst an apparent "Colored Revolution", what is in dispute is not a Regime Change (the Brazilian political class is well articulated), but the erosion of President Dilma prestige, the revival of a weakened opposition and an alteration of the ruling coalition. Ironically, the name of President Lula reappears in opinion polls as the most preferred by the electorate for the next year's election. There is no "corruption wave", but a strife for the distribution of investment and public resources.

Therefore, thanks to the demonstrations, the government shall react to its excessive confidence and recover decision-making, which characterized the Lula administration. Economy, in spite of the limited growth, keeps its stability, prosperity and vitality up. This is a political crisis in a democratic regime in full vigor, which seems to be losing strength through the authorities' reaction and the self-criticism of political parties. Brazil, unlike other South American nations, shunned the most negative aspects legated by the military regime and neoliberalism, and it also must overcome the present difficulties, in most part derived from the accelerated social transformations experienced during the past decade. In order to do that, Brazil nonetheless has to reconsider 
certain aspects of its economic model and its political system, and also to set more strength to foreign policy.

By releasing its fourth edition, AUSTRAL: Brazilian Journal of Strategy \& International Relations completes its second year of existence. In the present number, the issues covered are: the strategic dimension of the South Atlantic; BRICS; the new dimensions and actors of Brazilian foreign policy; the climate question in emerging countries; and also the Latin American integration. In this edition, the journal has already obtained its first qualification by the CAPES' Qualis and will also appear in new indexes. But the most important is that it is consolidating its links to other academic centers, especially from developing nations. We thank the support of the Advisory Board for Cooperation and International Relations - Governor of Rio Grande do Sul's Office, as well as the work of the Editor Assistant, Pedro Alt, and the translation team. 